\title{
The Needs for Teaching Factory Learning in Motorcycle Tune-Up Practices in Mechanical Engineering Education
}

\author{
$1^{\text {st }}$ Nurcholish Arifin Handoyono ${ }^{1}, 2^{\text {nd }}$ Sigit Purnomo $^{2}, 3^{\text {rd }}$ Rabiman $^{3}$ \\ \{arifin@ustjogja.ac.id ${ }^{1}$, sigitpurnomo@ustjogja.ac.id ${ }^{2}$, rabimanust@yahoo.com ${ }^{3}$ \\ Mechanical Engineering Education Department $1^{23}$, Universitas Sarjanawiyata Tamansiswa \\ Yogyakarta, Indonesia ${ }^{123}$
}

\begin{abstract}
The study aims to: (1) Identify the learning needs analysis of motorcycle tuneup practices; and (2) Knowing the availability of learning needs for motorcycle tune-up practices with teaching factory concepts in Mechanical Engineering Education at the Faculty of Teacher Training and Education at Universitas Sarjanawiyata Tamansiswa. The type of research is a case study with a qualitative approach to determine the needs of motorcycle tune-up practices with the teaching factory concept. The research subjects were the head of the laboratory and the object of the study was the learning needs of motorcycle tune-up practices. Data collection by observation, interviews, and documentation. The data obtained were analyzed qualitative descriptive. The results showed that: (1): The learning needs analysis of motorcycle tune-up practices with the factory teaching concept consists of three processes, namely: (a) Preparation; (b) Learning; and (c) Evaluation. The preparation process includes: (a) Management of facilities and infrastructure (tools and machinery); (b) Room management; and (c) Determination of strategies used in the practice learning process. The learning process includes: (a) the initial process of learning; (b) The process of implementing practical learning; and (c) the final process of learning. The evaluation process includes an assessment with several indicators, namely: (a) Work preparation; (b) Work process; (c) Work results; (d) work attitude; and (e) time; and (2) the description of the equipment owned by the Production Unit of the Motorcycle Workshop of mechanical engineering education contained 25 equipment with details of 16 equipment or $48.48 \%$ which were used classically, while 17 equipment or $51.52 \%$ were used in groups. Of this equipment there are 7 equipment or $21.21 \%$ including the very satisfy category, 7 equipment or $21.21 \%$ including the satisfy category, 4 equipment or $12.12 \%$ including the neither dissatisfy category, 13 equipment or $39.40 \%$ including the less dissatisfy category, and 2 equipment or $6.06 \%$ included very dissatisfy category. Overall obtained a percentage of $80.30 \%$, meaning that the equipment is in the satisfy category.
\end{abstract}

Keywords: motorcycle tune-up, teaching factory 


\section{Introduction}

Education is a media in creating and forming Human Resources (HR). Based on the purpose of education in the formation of human resources who are ready to enter the world of work, especially in vocational education there are still many problems encountered. Through vocational education ideally graduates are able to be absorbed in the workforce well. Nonetheless, the Indonesian Ministry of Manpower noted that most graduates of Vocational Schools were unemployed and had not yet had a place to work, reaching $10 \%$ of the 7.01 million unemployed people (https://ekonomi.kompas.com/read/2017/10/02/163324126/ kemenaker-alumni-smk-terbanyak-menganggur). Seeing this fact is an irony because graduates from vocational education are graduates ready to use in the world of work.

One form of vocational education in Mechanical Engineering Education at the Faculty of Teacher Training and Education at Universitas Sarjanawiyata Tamansiswa, Yogyakarta. Mechanical Engineering Education is an Educational Institution and Education Personnel whose goal is to create vocational teacher candidates with 2 specialization options, namely production engineering and automotive engineering. In order to produce qualified vocational teacher candidates, according to Minister of National Education Regulation Number 16 of 2007 concerning the standards of academic qualifications and teacher competencies, Mechanical Engineering Education must be able to produce professional technical education graduates who are competent in the field of education and mechanical engineering. personality, nationalism, and patriotism, critical, creative and innovative, democratic, independent, and sensitive to the development of mechanical engineering technology and ability to compete globally.

As vocational teacher candidates, students must be able to keep up with technological developments related to their scientific fields so that later they can teach students with the current material. Indonesian president Jokowi stated that most teachers in vocational schools were dominated by normative subject teachers, not practical (https://nasional. kompas.com/read/2017/02/02/13493711/jokowi.ungkap.fakta.miris.soal.lulusan.smk). With this statement indicates that learning in vocational schools is still much theoretical. This is not in accordance with the characteristics of work-oriented vocational education.

Other facts related to the low quality of teachers in Indonesia are expressed by Hurriyati (2016), namely: (1) The average competency of teacher candidates based on the ability to answer competency test questions when conducting teacher candidates tests is still below $50 \%$, which is only 44\%; (2) Pedagogic average competency based on 2015 teacher competency test data is $56.69 \%$; (3) The quality of teachers based on the origin of higher education is different, but not significant (the results of the 2015 teacher competency test assessment); (4) Distribution of the average ability of teachers from the best order: Java, Sumatra, Kalimantan, Sulawesi, Nusa Tenggara-Maluku-Papua; (5) There are no significant differences between teacher competency test results in the district and in the city; (6) The results of the teacher competency test decreased sharply after the age of 41 years; (7) Nongovernment civil servant teachers have the lowest teacher competency test scores; (8) There is no significant difference between certified teacher competency and teacher's competence not certified; and (9) The higher the qualification (teacher's final education level), the better the teacher competency test value.

Based on the condition of teachers in Indonesia, which is largely based on the results of the 2015 teacher competency test, it can be analyzed that the quality of Educational Institution 
and Education Personnel still needs to be improved. The results of a relatively low pedagogic ability indicate that the need for hard work from the Educational Institution and Education Personnel to improve the quality of its graduates. The drastic decline in the results of teacher competency examinations at the age of 41 is a very interesting fact because there are many possible factors. One possibility is the low motivation to learn for teachers after the age of 40, so that their abilities are not updated anymore. Older teachers tend to be reluctant to be technologically literate, so that the material taught to their students is outdated technology.

So that the Mechanical Engineering Education at the Faculty of Teacher Training and Education at Universitas Sarjanawiyata Tamansiswa can graduate teacher candidates who can follow technology trends, Prosser \& Quigley (1950) suggest that: (1) Vocational education will be efficient if the environment in which students are trained is an environmental replica where will he work; (2) Effective vocational education can only be given where the training tasks are carried out in the same way, tools and machines as stipulated in the workplace; and (3) Vocational education will be effective if training someone in the habit of thinking and working as needed in the work itself. In this case, the learning process on campus, especially practical learning must always be synergized with the developments on the market.

Workshop is a place used by students in practical learning. Workshop is an important factor in practical learning. This is in line with Djohar (2006) which states that the effectiveness of the learning process in the "indoor" laboratory is very dependent on the facilities available in it. By considering the importance of workshops in practical learning, then to maximize the use of space, facilities, and infrastructure, good workshop management is needed regarding planning, organization and implementation.

According to the President's instruction Number 9 of 2016 in order to improve the quality of teachers in order to produce qualified graduates of vocational schools, one of the efforts that can be done is through the development of teaching factories. According to Yahya (2006), "teaching factory concept as an approach that combines learning and working environment from which realistic and relevant learning experiences arise". Teaching factory combines the learning process in a realistic work environment to bridge the competency gap between given in campus and needs in the industry, so that the hope of the occurrence of knowledge gained by students as prospective teachers with the development of science and technology can be fulfilled.

The factory teaching can be developed using the Production Unit. The Mechanical Engineering Education at the Faculty of Teacher Training and Education at Universitas Sarjanawiyata Tamansiswa has developed a Production Unit in the form of a motorcycle workshop which was established in February 2018. This production unit is one of the University's quality improvement programs from Mechanical Engineering Education which aims to be designed as a place to manage and improve the capabilities and skills of human resources, especially entrepreneurship skills, in addition, it is also an effort to optimize the use of campus facilities that can provide added value.

Learning motorcycle engineering practices is a compulsory subject for students of mechanical engineering education in the concentration of automotive mechanics. The achievement of the competencies of this course is that students have competencies about motorcycle s that include tune-ups, engines, electricity, and chassis. This motorcycle workshop production unit can be used as a support facility and infrastructure in learning motorcycle engineering practices. Even so, at present, the learning process of motorcycle 
practice is still less than optimal. This is indicated by the lack of practice facilities and infrastructure that are owned if adjusted to the needs of the number of students. In addition, there are still many tools such as keys, measuring instruments and engines that are not used to support practical learning.

\section{Teaching Factory}

Teaching Factory is a model that in the implementation of education fully integrates learning and work, no longer separates between the place of delivery of theoretical material and the place of production material (practice). The concept of teaching factory is found for three things, namely: (1) ordinary learning is not enough; (2) Student benefits are obtained from hands-on practical experience; and (3) The experience of team-based learning involving students, lecturers and industrial participation enriches the educational process and provides tangible benefits for all parties (Lamancusa et al., 2008).

Alptekin, Pouraghabagher, McQuaid, and Waldorf (2001), state:

"The Teaching Factory will have dual purposes. One is to enable students to develop smallscale industrial products or consumer goods. The development will involve creating a prototype,... The basic concept of the Teaching Factory and progress to date are presented in the following sections. More information on various ongoing projects can be found at the Teaching Factory web site."

The statement above means that the teaching factory has a dual purpose. One of them is to enable students to develop small-scale industrial products or consumer goods. In the application of teaching factory on campus, the team involved in providing service or production services is part of the lecture process. Because the production unit developed in mechanical engineering education is a motorcycle service workshop, the need to be identified is learning the practice of motorcycle s, especially in the competency of motorcycle tune-up. This competence was chosen because Tune-up is a job that is often done mostly by motorcycle workshops.

According to Hadlock, Wells, Hall, Clifford, Winowich, and Burns (2008), the teaching factory's objectives are:

"The goal of learning factory is to change that and teach students more than what is in the book. Not only do students practice the "soft skill," in the Learning Factory, such as teamwork and interpersonal communication skills, but also get the crucial hands on experience an future job training. "Learning Factory participants learn how to define a problem, build a prototype, write a business proposal, and make a presentation about their solution. In the process, the students learn critical skill, such as how to meet deadlines and expectations, build and work on multidisciplinary teams, and use people's varied talent...".

With the teaching factory will make students aware, that in learning not only practice soft skills, but learn to work in teams, practice interpersonal communication skills, get experience directly. With this kind of learning, it is expected that students' knowledge and insight will always be updated. This updated knowledge and insight will be taught by students later by mechanical engineering education students as prospective teachers. In addition to increasing students' knowledge and insight, the teaching factory will also teach students to always be ready to work in the industrial world as an alternative search for jobs other than in the world of education. 
Learning needs of motorcycle practices that will be identified include: (1) The preparation process which includes the management of facilities and infrastructure (tools and machinery) and management of the room. The preparation process is carried out with the aim of preparing what things are needed; (2) The learning process that involves students in full starts from the preparation process, practicum process, and the final process of practical activities. The type of practice activities that are carried out no longer use a system of training objects but carry out the practice directly on a real object or a motorcycle owned by a consumer. All practical learning processes carried out are based on the teaching factory concept; and (3) The evaluation process which includes direct observation of the process and work of students by using observation and evaluation sheets based on the guidelines of the Expertise Competency Test presented in the form of practice exams.

\section{Motorcycle Tune-up}

Each motorcycle that is operated will eventually experience a situation where the parts of the motorcycle (engine, electricity, chassis, etc.) experience fatigue and wear, thereby reducing its performance, including: decreased engine power, slow acceleration, wasteful fuel, and the possibility of damage continues/spreads to damage to other components. If these conditions are not addressed through periodic maintenance of the vehicle, then the condition will increase towards the deterioration of the component which gets worse and requires substantial funds to return the motorcycle to its original condition.

Based on the problems above, it is necessary to tune-up a motorcycle. The understanding of the tune-up is to condition the machine back to normal after daily use, the tune-up itself is not an improvement but more on regular maintenance, the maintenance includes checking, testing, adjusting and replacing components that need to be replaced (Saraswo, 2012). Then Rabiman and Arifin (2011), stated that periodic maintenance is an effort to take care of vehicle parts that are carried out periodically (routine) in the hope that the vehicle can function properly and optimally. Motorcycle tune-up activities are periodic maintenance activities on motorcycle $\mathrm{s}$ in an effort to restore normal conditions. Motorcycle tune-up activities include engine, electrical and chassis checks.

\section{Method}

This Design of research is a case study with a qualitative approach to finding out the learning needs of motorcycle tune-up practices with the teaching factory concept in The Mechanical Engineering Education at the Faculty of Teacher Training and Education at Universitas Sarjanawiyata Tamansiswa.

The research was carried out in the Production Unit of the Mechanical Engineering Education at the Faculty of Teacher Training and Education at Universitas Sarjanawiyata Tamansiswa. The study was conducted for 6 months from May to October 2018.

The research subjects were the head of the laboratory and the object of the study was the learning needs of motorcycle tune-up practices.

The research data source used is primary and secondary data. Primary data is obtained through observation, documentation, and interviews, while secondary data is obtained through 
documentation data and supporting data in the form of data on equipment inventory of motorcycle workshop units.

Data analysis techniques were carried out using qualitative descriptive analysis of the learning needs of motorcycle tune-up practices with the teaching factory concept. In qualitative research, data can be grouped into categories based on the following percentage (Pohan, 2007):

Table 1. Assessment Guidelines

\begin{tabular}{|c|c|c|}
\hline No. & Percentage (\%) & Category \\
\hline 1. & $0-25$ & Very dissatisfy \\
\hline 2. & $26-50$ & Less dissatisfy \\
\hline 3. & $51-75$ & Neither dissatisfy \\
\hline 4. & $76-100$ & Satisfy \\
\hline 5. & $>100$ & Very satisfy \\
\hline
\end{tabular}

\section{Result and Discussion}

\subsection{Learning Needs Analysis of Motorcycle Tune-up Practices with Teaching Factory Concept}

Learning Needs Analysis of Motorcycle Tune-up Practices with Teaching Factory Concept consists of three processes, namely preparation, learning, and evaluation.

The preparation process is carried out with the aim of preparing what things are needed in learning to practice motorcycle tune-up with the teaching factory concept. The effectiveness of learning practices is influenced by practical learning methods, understanding the character of students, and evaluating practical learning individually or jointly on the effectiveness of practical learning. Practical learning is strongly influenced by the method used, the understanding of the lecturer/instructor on the characteristics of students and the evaluation process that will be carried out in knowing the level of competence obtained by students. In the preparation process carried out for learning motorcycle tune-up practices in mechanical engineering education include: (1) Management of facilities and infrastructure (tools and machinery); (2) Room management; and (3) Determination of strategies used in the practice learning process.

The learning process includes 3 activities, namely: (1) the initial process of learning; (2) The process of implementing practical learning; and (3) the final process of learning. The learning process with the teaching factory concept is a learning activity where students directly conduct production activities in the form of goods or services within the campus environment. In this case, the product produced is a motorcycle tune-up service. This is consistent with Triatmoko (2009) which states that the facilities and infrastructure owned by the campus that carry out teaching factory $60-70 \%$ are used for business/production activities. In the learning process of motorcycle tune-up practice with the teaching factory concept there are several provisions in its implementation, namely: (1) Students do work in accordance with the Standard Operating Procedures such as in the industrial world; (2) The practical material that is carried out is the vehicle belonging to the customer; (3) Job work based on problems found in customer vehicles; (4) Work based on work standards is supported by the provision 
of service manuals for the types of vehicles that are carried out; (5) Students are required to work based on the same working time in the industrial world; (6) Work safety is improved by humans, tools and work objects; and (7) Planting a greater sense of responsibility, especially towards customer satisfaction.

The evaluation process is carried out namely direct observation of the process and the work done by students using the observation sheet. Indicators used in the assessment are work preparation, work process, work results, work attitude, and time. The indicator refers to the Vocational schools Expertise Competency Test guidelines that have been adapted for universities. The assessment can also be carried out with a separate time by providing time for practice exams.

\subsection{Analysis of the Availability Level of Learning Needs for Motorcycle Tune-up \\ Practices with the Teaching Factory Concept}

Based on the results of the study, it can be seen that the availability of equipment owned by the Production Unit of Motorcycle Workshop on mechanical engineering education in the classical usage (1 class) is $48.48 \%$ and $51.52 \%$ in groups. Classic use of equipment because not all equipment in the tune-up work requires this equipment. Classic equipment is needed if there is heavy work or specialized in handling customer vehicles. Because in practical learning nature is in groups, the availability of preferred tools is those used in groups. Equipment in this group is often used in practical activities, especially on motorcycle tune-up. This group of equipment contains standard equipment used in motorcycle tune-up work.

In the implementation of learning motorcycle tune-up practices, one study group consisted of six study groups with four students. Based on the study group, it was obtained the ratio of the needs and availability of equipment owned by the Production Unit of the mechanical engineering education workshop as follows:

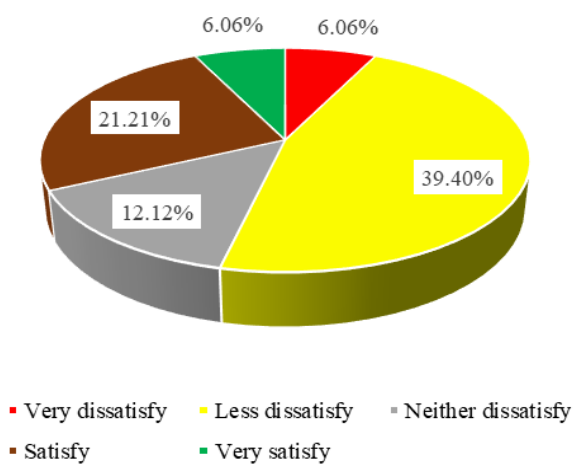

Fig.1. Ratio of Equipment Needs and Availability Used in Learning Motorcycle Tune-up Practices with The Teaching Factory Concept

Based on Figure 1 consists of 7 equipment or $21.21 \%$ of equipment including very satisfy category, 7 equipment or $21.21 \%$ including satisfy category, 4 equipment or $12.12 \%$ including neither dissatisfy category, 13 equipment or equal to $39.40 \%$ including less dissatisfy category, and 2 equipment or $6.06 \%$ including very dissatisfy category. Overall obtained a percentage of $80.30 \%$, meaning that the equipment is in the satisfy category. 
Facilities and infrastructure that are complete in fiber to meet the competency standards of the industrial world are one of the main needs for vocational education providers. This is because the facilities and infrastructure that are complete and in accordance with the competency standards of the industrial world will help students in an effort to improve their skills and expertise in accordance with their respective fields of science. This is consistent with Prosser \& Quigley (1950) suggesting that: (1) vocational education will be efficient if the environment in which students are trained is a replica of the environment in which it will work; (2) Effective vocational education can only be given where the training tasks are carried out in the same way, tools and machines as stipulated in the workplace; and (3) Vocational education will be effective if training someone in the habit of thinking and working as needed in the work itself; and so forth.

The fulfillment of facilities and infrastructure is expected to create a real work environment in accordance with the industrial world. With the teaching factory concept is expected to provide real work in accordance with the industrial world in the form of motorcycle tune-up services. This concept is also expected to create a work pattern for students because students are given the responsibility to complete their work on the customer's motorcycle.

In the learning process, not only complete facilities and infrastructure are needed so that they can be done well. Lecturers/instructors are needed in the learning process so that the transfer of knowledge to students can occur. In accordance with Hartoyo (1999) which reveals that mastery of material can be influenced by the experience of teaching practice in the field of industry, therefore the lecturer who teaches the practice of tune-up motorcycle $s$ with the teaching factory concept must be competent. This was reinforced by Djojonegoro (1998) who stated that vocational education would be effective if the instructor had successful experience in the application of skills and knowledge to the operations and work processes to be carried out. In this case, the lecturer/instructor is competent in the field of motorcycle tune-up.

\section{Conclusions}

Based on the results of the research and discussion that has been done can be concluded as follows:

First, the learning needs analysis of motorcycle tune-up practices with the factory teaching concept consists of three processes, namely: (1) Preparation; (2) Learning; and (3) Evaluation. The preparation process includes: (1) Management of facilities and infrastructure (tools and machinery); (2) Room management; and (3) Determination of strategies used in the practice learning process. The learning process includes: (1) the initial process of learning; (2) The process of implementing practical learning; and (3) the final process of learning. The evaluation process includes an assessment with several indicators, namely: (1) Work preparation; (2) Work process; (3) Work results; (4) work attitude; and (5) time.

Secondly, the description of the equipment owned by the Production Unit of the Motorcycle Workshop of mechanical engineering education contained 25 equipment with details of 16 equipment or $48.48 \%$ which were used classically, while 17 equipment or $51.52 \%$ were used in groups. Of these equipment there are 7 equipment or $21.21 \%$ including the very satisfy category, 7 equipment or $21.21 \%$ including the satisfy category, 4 equipment 
or $12.12 \%$ including the neither dissatisfy category, 13 equipment or $39.40 \%$ including the less dissatisfy category, and 2 equipment or $6.06 \%$ included very dissatisfy category. Overall obtained a percentage of $80.30 \%$, meaning that the equipment is in the satisfy category.

\section{Acknowledgment}

This research is based upon work supported by LP3M UST.

\section{References}

[1] Teaching Factory Proceedings of the 2001 American Society For Engineering Education Annual Conference \& Exposition. San Luis Obispo, 3563

[2] Djojonegoro, Wardiman. (1998). Pengembangan sumber daya manusia melalui Sekolah Menengah Kejuruan (SMK). Jakarta: PT. Jayakarta Agung Offset.

[3] Hadlock, H., Wells, S., Hall, J., et al. (2008). From practice to entrepreneurship: rethingking the learning factory approach. Proceeding of the 2008 IAJC IJME International Conference, ISBN 978-1-60643-379-9.

[4] Hartoyo. (1999). Kemampuaan mengajar praktik guru Sekolah Mengah Kejuruan Negeri (SMKN) jurusan listrik di Kota Madya Yogyakarta. Thesis, not published, Universitas Negeri Yogyakarta: Yogyakarta.

[5] Lamancusa, John s., Zayas, Jose L., Soyster, Allen L., et al. (2008). The learning factory: industry-partnered active learning. Journal of engineering education 97(1). January 2008.

[6] Pohan, Rusdian. (2007). Metodologi penelitian pendidikan. Yogyakarta: Lanarka dan Ar Rijal Institute.

[7] Prosser, C.A. \& Quigley, T.H. (1950). Vocational education in a democracy. Revised Edition. Chicago: American Technical Society.

[8] Rabiman dan Arifn, Zainal. (2011). Sistem bahan bakar motor diesel. Yogyakarta: Graha Ilmu.

[9] Saraswo, Aris Joko. (2012). Tune-up mobil EFI. Yogyakarta: Bintang Cemerlang.

[10] Triatmoko. (2009). The ATMI Story, rainbow of excellence. Surakarta: Atmipress.

[11] Yahya, N.M. (2006). An overview of teaching factory concept. (Electronik version). Vocational educatin paper: Universitas Pendidikan Indonesia: Bandung.

[12] Hurriyati, Ratih. (2016, March 1). Kualitas guru kita. Retreived from http://www.pikiranrakyat.com/opini/2016/05/04/kualitas-guru-kita-368286

[13] Cipto, Hendra. (2017, March 1). Kemenaker: Alumni SMK terbanyak menganggur. Retreived from https://ekonomi.kompas.com/read/2017/10/02/163324126/kemenaker-alumni-smk-terbanyak-menganggur.

[14] Kuwado, Fabian Januarius. (2017, March 1). Jokowi ungkap fakta miris soal lulusan SMK. Retreived from https://nasional.kompas.com/read/2017/02/02/13493711/jokowi.ungkap.fakta.miris.soal.lulusan.smk. 